\title{
THE RELATIONSHIP BETWEEN ENGAGEMENT SOFTWARE ANALYSIS AND FINAL GRADES IN ONLINE COURSES
}

\author{
Robert Kowalewski, Robert Morris University,rwkst5@mail.rmu.edu \\ Michael J. Curran, Strayer University, michael.curran@strayer.edu \\ Barbara Burgess-Lefebvre, Robert Morris University, lefebvre@rmu.edu
}

\begin{abstract}
The move to greater usage of online modalities for college students is well documented. More and more universities are developing and enlarging their online program offerings to accommodate this shift in learning preference. As a result, universities are consistently trying to increase the likelihood of success for students in the online environment. There is also ample evidence that highly engaged students are more successful online than those who are not as participative. This study assessed the relationship between a software program developed by Civitas, which measures student engagement on a number of variables and student success, as measured by final grades achieved by students. Results indicate that the program is highly successful in predicting student outcomes very early in a term, which can give faculty a significant edge in developing early intervention strategies for students who are at risk.
\end{abstract}

Keywords: Civitas, Online Education, Student Engagement, Quantitative Analysis, Correlational Analysis, Engagement App

\section{INTRODUCTION}

The increase in students' preference for online education has been well documented (Allen \& Seaman, 2008, 2014). As more and more students opt for this modality of learning, it becomes increasingly important for universities to adopt strategies that contribute to student success in online environments (Allen,Seaman \& Sloan, 2007). One of the factors most often cited as a critical success element is engagement (Fuller, Wilson, \& Tobin, 2011; Kuh, 2001; Kuh, March/April, 2003). Online learning often requires a higher degree of autonomy on the part of the learner and a strong commitment to self-discipline in prioritizing the many things that often distract online learners from achieving their educational goals (Johnson \& Aragon, 2003; Yearwood, Cox, \& Cassidy, 2016). There has been much research demonstrating that students who highly engage course material within a learning management system tend to be more successful (Durrington, Berryhill, \& Swafford, 2006; Fredrickson, 2015; Kuh, Kinzie, Buckley, Bridges, \& Hayek, 2006). Therefore, if engagement as a concept can be effectively measured, it can give institutions and faculty more reliable information about online learners that can lead to proactive early interventions increasing student success. The research question addressed by this study was: is there a relationship between scores established by engagement measuring software and learning outcomes? This question should be of importance to any institution that offers online learning programs as well as developers of education software programs.

\section{LITERATURE REVIEW}

Online education has become an increasingly important component of higher education (Allen \& Seamen, 2014; Allen, Seamen, \& Sloan, 2007). There have been consistent increases in the number of schools offering online courses, and in fact, fully online degree programs. The number of students expressing a preference for this modality has also increased in recent years (Allen \& Seamen, 2008; Allen, Seamen, \& Sloan, 2007). There continues to be much research on factors that contribute to success in online learning (Benson, 2003; Credence, 2010; Harris, Sklar, Amend, \& Novalis-Marine, 2010). Much research focuses on the personal characteristics of the learner, citing that these factors greatly influence the likelihood of success (Friedlander \& MacDougall, 1992; Shea, Li, \& Pickett, 2006; Tello, 2007). Other research has focused on the pedagogical development of the courses themselves (Astin, 1999; Garrison \& Cleveland-Innes, 2005). Additionally, there continues to be somewhat conflicting research as to whether the student or the faculty member is a more compelling factor in overall success for students (Annad, 2011; 
Hrastinski, 2009). There has also been much recent research into factors that contribute to student success in online learning. Some research indicates that cultural changes in student populations, including a distinct preference for video instruction in online learning, can be critical success factors in developing online courses that effectively teach students (Draus, Curran, \& Trempus, 2014; Pinsk, Curran, Poirier, \& Coulson, 2014). There is also some compelling research that connection to a faculty member needs to be established early on for many online learners (Annad, 2011; Brinthuapt, Fisher, Gardner, Raffalo, \& Woodard, 2011; Nippard \& Murphy, 2007).

One consistent factor that is cited in the literature is the concept of engagement (Lewis, Freed, Heller, \& Burch, 2015; National Survey, 2007). Students that approach online learning passively exhibiting behaviors such as infrequent logins, short and rare discussion posts and late submission of assignments tend to do very poorly in these environments. On the other hand, students that are highly engaged in the course and exhibit those types of behaviors, including frequent logins and consistently participating in online activities such as discussions, tend to do better. While the term engagement itself has not been fully defined, there remains some general consensus on behaviors that engaged students exhibit (Carini, Kuh, \& Klein, 2006; Chen, Kuh, \& Gonyea, 2008; Miller, 2012). Much research highlights participation in discussions, grade consciousness, and consistent behaviors related to logging in frequently as indicative of engaged behaviors. There have also been some attempts to classify and measure activity and engagement as indicators of student success in online learning (Azvedo, 2015; Burch, Heller, \& Freed, 2014; Dixon, 2015).

There have been efforts to quantify engagement as a measurable variable that can be used to assess the influence that it has on student outcomes, but the results have been mixed (Handelsman, Briggs, Sullivan, \& Towler, 2005; Kuh, Kinzie, Schuh, \& Whitt, 2005; Ouimet \& Smallwood, 2005; Robinson \& Hullinger, 2008; Swerdzewski, Miller, \& Mitchell, 2007). The development of an 'Engagement App' by Civitas presented a unique opportunity to test whether or not engagement can be measured and if there is a relationship between levels of engagement and course outcomes (Kuh, Cruce, Shoup, Kinzie, \& Gonyea, 2008). It is in this area that this study adds to the body of knowledge on online learning.

\section{RESEARCH METHODOLOGY}

The primary determinant of data about student engagement for this study was a program developed by Civitas. Civitas developed an 'Engagement App' that uses a highly sophisticated algorithm to measure over 40 disparate factors that contribute to engagement. While the term engagement itself is highly subjective, Civitas defines engagement on enough different variables to make a solid claim to being inclusive of most major areas. It includes variables such as: number of days logged into course, number of discussion posts viewed, number of assignments submitted, number of grade book checks, etc. These variables are weighted and developed through an algorithm to arrive at an 'Engagement Score' based on a zero to ten scale. The scores are then aggregated and totaled for all students taking that same course throughout the university. Each course is differentiated since not all online courses require the same amount of assignments, time commitments, discussions, or expectations. Therefore, Civitas scores students against all other students taking that exact same course. In this case, all students in the sample were taking an introductory marketing course and all sections were taught by the same professor. The scores are then distributed, with the top $20 \%$ of the scores equating to 'very highly engaged', the next $20 \%$ as 'highly engaged', the middle $20 \%$ as 'moderately engaged', followed by the next $20 \%$ as 'low engagement' and finally the bottom $20 \%$ as 'very low engagement'. The groups are then color coded for faculty ease of use and presented in the following format (See Table 1). 


\section{Issues in Information Systems}

Volume 17, Issue I, pp. 136-148, 2016

Table 1. Overview of Student Engagement Data for a Course

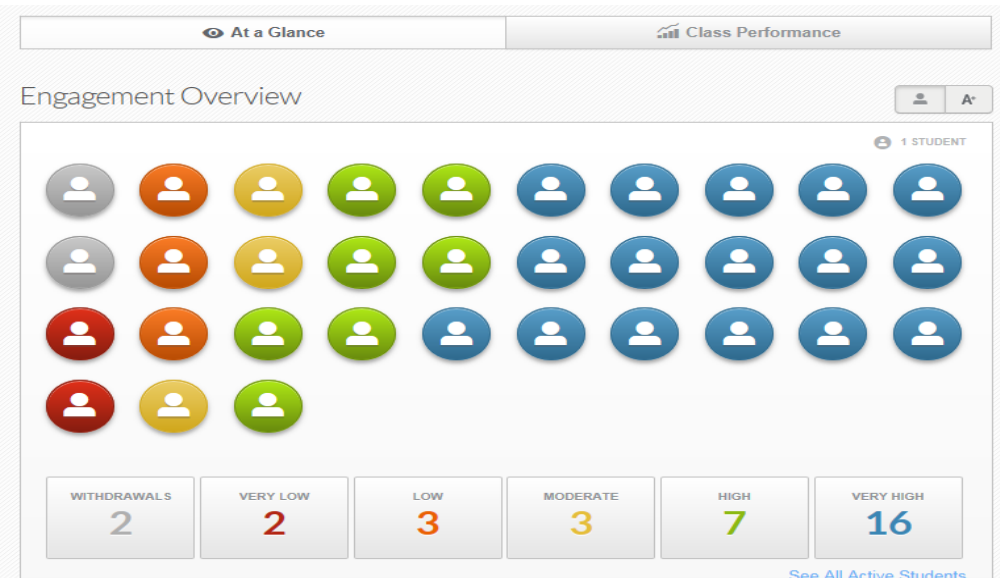

This data is consistently updated for faculty so that faculty can get an almost 'real time' assessment on the engagement of any particular student. The app also allows for faculty to 'drill down' on several key metrics for each individual student and measures each metric against all other students taking that course across the university. (see Table 2).

Table 2. Individual Engagement Data for student:

\begin{tabular}{|c|c|c|c|c|}
\hline \multicolumn{5}{|l|}{ Nicole's Statistics } \\
\hline Activity & Last Week & Week to Date & Overall to Date & Activity Engagement Percentile \\
\hline Discussion Board Replies & 3 & 0 & 39 & ध日司 \\
\hline Grade and Comment Checks & 0 & 0 & 2 & a \\
\hline Gradable Items Completed & 4 & 0 & 30 & घ日a \\
\hline Unique Discussion Participation & 1 & 0 & 10 & घோ- \\
\hline Total Discussion Board Views & 4 & 0 & 43 & घ曰घ \\
\hline Total Discussion Thread Views & 5 & 0 & 41 & घேघா \\
\hline Replies to Unique Students & 2 & 0 & 14 & $=\square=0$ \\
\hline Longest Course Visit Gap (in days) & N/A & N/A & 6.5 & घDயம \\
\hline Total Unique Days Visited Course & N/A & N/A & 41 & घ日回 \\
\hline
\end{tabular}

The app also charts trends for the student in engagement and offers 'recommended outreach' when it detects behaviors such as 'student has moved from low engagement to very low engagement' or 'student has two consecutive absences' (see Table 3). 
Table 3. Analytic Data on Individual Student Metrics from Civitas Engagement App
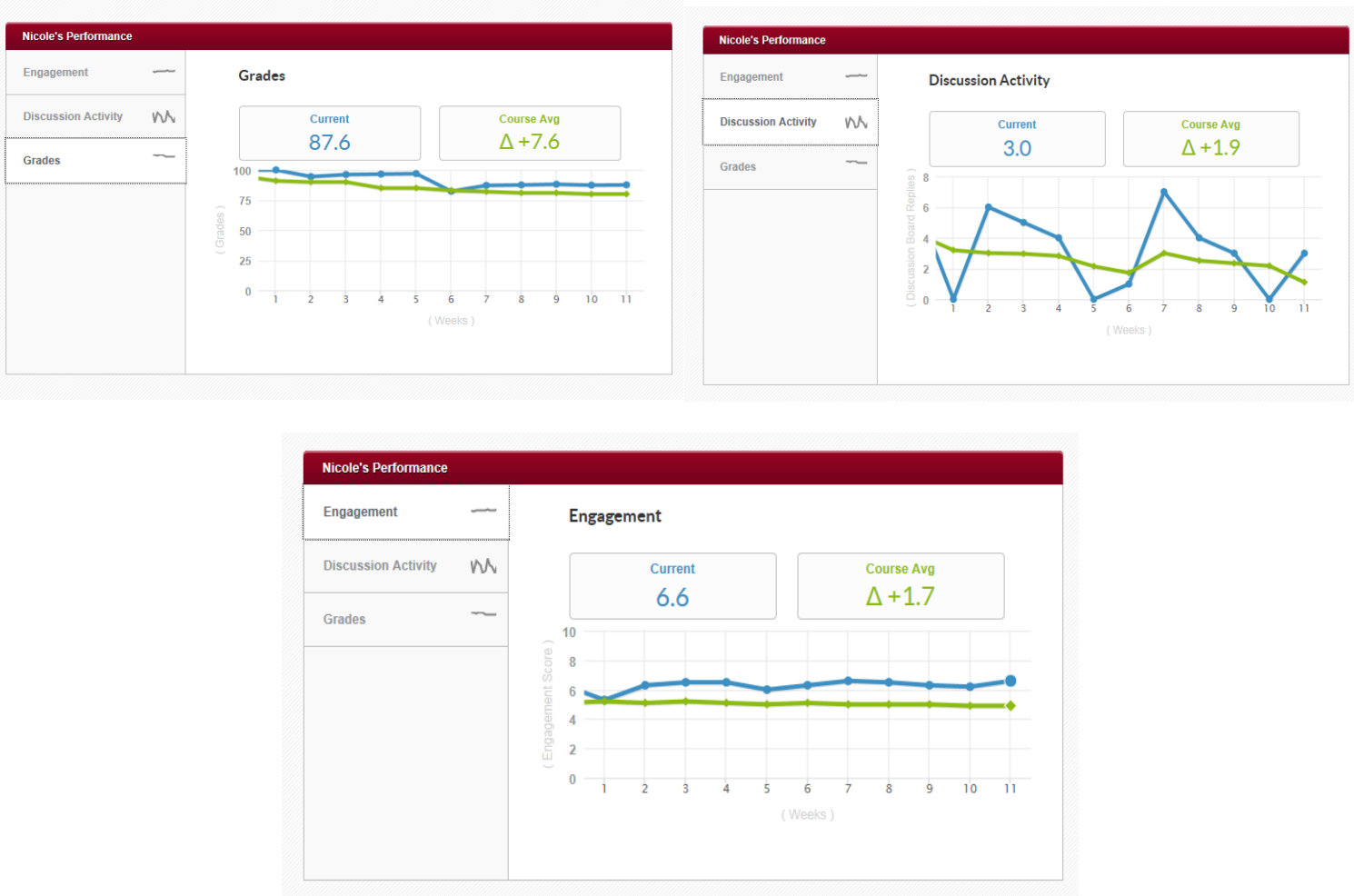

While not designed to specifically equate engagement levels with grades, this study sought to determine the strength of the relationship between 'engagement status' as defined by the Civitas algorithm and learning outcomes, which were defined in terms of final course grades. An experimental design was set up using historic data from 10 sections of an introductory marketing course taught online by a single professor over a period of 3 terms at a large university with an extensive offering of online courses. The student population includes primarily first and second term business students. The courses each ran for 11 weeks and during each week, the engagement status of the student was determined (the metric was taken each Sunday since the deadline for weekly submissions of work was each Sunday at midnight) and scored on a 1 to 5 scale, and final course grades were also assigned values from to 1 to 5 , which are summarized in the table below (Table 4):

Table 4. Correlational Matrix used for Analysis:

\begin{tabular}{|l|c|c|c|c|c|}
\hline Engagement Status & $\begin{array}{c}\text { Very Highly } \\
\text { Engaged } \\
\text { (blue icon) }\end{array}$ & $\begin{array}{c}\text { Highly Engaged } \\
\text { (green icon) }\end{array}$ & $\begin{array}{c}\text { Moderately } \\
\text { Engaged (yellow } \\
\text { icon) }\end{array}$ & $\begin{array}{c}\text { Low Engagement } \\
\text { (orange icon) }\end{array}$ & $\begin{array}{c}\text { Very Low } \\
\text { Engagement } \\
\text { (red icon) }\end{array}$ \\
\hline Score & 5 & 4 & 3 & 2 & 1 \\
\hline Final Course Grade & $\mathrm{A}$ & $\mathrm{B}$ & $\mathrm{C}$ & $\mathrm{D}$ & $\mathrm{F}$ \\
\hline Score & 5 & 4 & 3 & 2 & 1 \\
\hline
\end{tabular}

\section{RESULTS}

Correlational analysis was then performed each week to assess the strength of the relationship between engagement status and final grades. The use of correlational analysis as means to assess the strength of the relationship between engagement status and final grades was appropriate given the type of data available for this study (Lomax, 2001). The study measured the strength of the relationship between engagement status (as determined by their Engagement 
App color code) and their Anticipated Final Grade (Very Highly Engaged $=$ A, Highly Engaged $=$ B, Moderately Engaged $=\mathrm{C}$, Low Engagement $=\mathrm{D}$, Very Low Engagement $=\mathrm{F}$ ). These results are summarized in the tables below (Table 5):

Table 5. Weekly Correlations between 'Engagement Status' and 'Final Course Grade'

Week 1:

\begin{tabular}{|l|c|c|c|}
\hline Engagement Status & Number of Students & Anticipated Grade & $\begin{array}{c}\text { Correlation between Engagement and } \\
\text { Anticipated Final Grade }\end{array}$ \\
\hline $\begin{array}{l}\text { Very Highly } \\
\text { Engaged }\end{array}$ & 89 & $\mathrm{~A}$ & +.35 \\
\hline Highly Engaged & 82 & $\mathrm{~B}$ & +.31 \\
\hline $\begin{array}{l}\text { Moderately } \\
\text { Engaged }\end{array}$ & 70 & $\mathrm{C}$ & +.27 \\
\hline Low Engagement & 60 & $\mathrm{D}$ & +.33 \\
\hline $\begin{array}{l}\text { Very Low } \\
\text { Engagement }\end{array}$ & 33 & $\mathrm{~F}$ & +.38 \\
\hline
\end{tabular}

Week 2:

\begin{tabular}{|l|c|c|c|}
\hline Engagement Status & Number of Students & Anticipated Grade & $\begin{array}{c}\text { Correlation between Engagement and } \\
\text { Anticipated Final Grade }\end{array}$ \\
\hline $\begin{array}{l}\text { Very Highly } \\
\text { Engaged }\end{array}$ & 84 & $\mathrm{~A}$ & +.41 \\
\hline Highly Engaged & 75 & $\mathrm{~B}$ & +.39 \\
\hline $\begin{array}{l}\text { Moderately } \\
\text { Engaged }\end{array}$ & 91 & $\mathrm{C}$ & +.30 \\
\hline Low Engagement & 52 & $\mathrm{D}$ & +.39 \\
\hline $\begin{array}{l}\text { Very Low } \\
\text { Engagement }\end{array}$ & 34 & $\mathrm{~F}$ & +.45 \\
\hline
\end{tabular}

Analysis indicates that there is little relationship between engagement and final course results by the end of week 2 ( $18.1 \%$ of the course completed). This was not a surprising result since the amount of activity in the course is somewhat limited in the first two weeks to online discussions and two self-paced learning modules.

Week 3:

\begin{tabular}{|l|c|c|c|}
\hline Engagement Status & Number of Students & Anticipated Grade & $\begin{array}{c}\text { Correlation between Engagement and } \\
\text { Anticipated Final Grade }\end{array}$ \\
\hline $\begin{array}{l}\text { Very Highly } \\
\text { Engaged }\end{array}$ & 80 & $\mathrm{~A}$ & +.57 \\
\hline Highly Engaged & 69 & $\mathrm{~B}$ & +.42 \\
\hline $\begin{array}{l}\text { Moderately } \\
\text { Engaged }\end{array}$ & 71 & $\mathrm{C}$ & +.35 \\
\hline Low Engagement & 60 & $\mathrm{D}$ & +.44 \\
\hline $\begin{array}{l}\text { Very Low } \\
\text { Engagement }\end{array}$ & 53 & $\mathrm{~F}$ & +.61 \\
\hline
\end{tabular}

There was a significant jump in the correlation between engagement and final grades at the conclusion of week 3 of the term ( $27 \%$ of the term completed). This was somewhat surprising because the first large writing assignment, 
which accounts for $15 \%$ of course grade in this class had not yet occurred (the assignment is in week 4). This was especially pronounced on the two extremes of engagement. 'Very Highly Engaged' students increased the correlation between that status and an A grade by $41.5 \%$ and 'Very Low Engagement' students' relationship between their status and the likelihood of an $\mathrm{F}$ grade by $35.6 \%$. It is possible that the development of 'engagement habits' has more fully coalesced after three weeks and therefore their overall behavioral patterns for the course are becoming more fully developed by this point. This might also indicate that there is a relationship between 'engagement' as defined by the Civitas App and outcomes as defined by final course grades.

Week 4:

\begin{tabular}{|l|c|c|c|}
\hline Engagement Status & Number of Students & Anticipated Grade & $\begin{array}{c}\text { Correlation between Engagement and } \\
\text { Anticipated Final Grade }\end{array}$ \\
\hline $\begin{array}{l}\text { Very Highly } \\
\text { Engaged }\end{array}$ & 81 & $\mathrm{~A}$ & +.61 \\
\hline Highly Engaged & 60 & $\mathrm{~B}$ & +.41 \\
\hline $\begin{array}{l}\text { Moderately } \\
\text { Engaged }\end{array}$ & 78 & $\mathrm{C}$ & +.38 \\
\hline Low Engagement & 44 & $\mathrm{D}$ & +.39 \\
\hline $\begin{array}{l}\text { Very Low } \\
\text { Engagement }\end{array}$ & 66 & $\mathrm{~F}$ & +.73 \\
\hline
\end{tabular}

While most of the correlations remained relatively stable in Week 4, there was a larger than expected increase in the relationship between 'Very Low Engagement Students' and failing final grades. Interestingly, of the 66 students in that group, 39 (59.1\% of the sample) did not submit the major paper due that week. The engagement score for that week was calculated before the paper was due, indicating a strong predictive aspect of the Civitas Engagement App and might provide some early intervention cues for faculty regarding these students. This might prove quite significant as 32 of the $39(82.1 \%)$ of students that did not submit this assignment either dropped the course or failed.

Week 5:

\begin{tabular}{|l|c|c|c|}
\hline Engagement Status & Number of Students & Anticipated Grade & $\begin{array}{c}\text { Correlation between Engagement and } \\
\text { Anticipated Final Grade }\end{array}$ \\
\hline $\begin{array}{l}\text { Very Highly } \\
\text { Engaged }\end{array}$ & 77 & $\mathrm{~A}$ & +.64 \\
\hline Highly Engaged & 53 & $\mathrm{~B}$ & +.47 \\
\hline $\begin{array}{l}\text { Moderately } \\
\text { Engaged }\end{array}$ & 83 & $\mathrm{C}$ & +.51 \\
\hline Low Engagement & 39 & $\mathrm{D}$ & +.49 \\
\hline $\begin{array}{l}\text { Very Low } \\
\text { Engagement }\end{array}$ & 59 & $\mathrm{~F}$ & +.76 \\
\hline
\end{tabular}

Week 5 saw very little change in either engagement status or the correlations between engagement status and final grades. This was somewhat surprising as the university issues mid-term grades to students at the end of week 5 and it was anticipated that engagement and submission of gradable work would have increased more during this week. However, that was not the case for this population. 
Week 6:

\begin{tabular}{|l|c|c|c|}
\hline Engagement Status & Number of Students & Anticipated Grade & $\begin{array}{c}\text { Correlation between Engagement and } \\
\text { Anticipated Final Grade }\end{array}$ \\
\hline $\begin{array}{l}\text { Very Highly } \\
\text { Engaged }\end{array}$ & 75 & $\mathrm{~A}$ & +.71 \\
\hline Highly Engaged & 59 & $\mathrm{~B}$ & +.57 \\
\hline $\begin{array}{l}\text { Moderately } \\
\text { Engaged }\end{array}$ & 82 & $\mathrm{C}$ & +.58 \\
\hline Low Engagement & 41 & $\mathrm{D}$ & +.58 \\
\hline $\begin{array}{l}\text { Very Low } \\
\text { Engagement }\end{array}$ & 60 & $\mathrm{~F}$ & +.78 \\
\hline
\end{tabular}

There was a modest increase in the correlation at the very high end of the engagement scale, as the correlation rose from .64 to .71. Additionally, the $\mathrm{C}$ range students also saw an increase in the correlation between their engagement status and their final grade.

Week 7:

\begin{tabular}{|l|c|c|c|}
\hline Engagement Status & Number of Students & Anticipated Grade & $\begin{array}{c}\text { Correlation between Engagement and } \\
\text { Anticipated Final Grade }\end{array}$ \\
\hline $\begin{array}{l}\text { Very Highly } \\
\text { Engaged }\end{array}$ & 70 & $\mathrm{~A}$ & +.74 \\
\hline Highly Engaged & 65 & $\mathrm{~B}$ & +.60 \\
\hline $\begin{array}{l}\text { Moderately } \\
\text { Engaged }\end{array}$ & 80 & $\mathrm{C}$ & +.61 \\
\hline Low Engagement & 38 & $\mathrm{D}$ & +.63 \\
\hline $\begin{array}{l}\text { Very Low } \\
\text { Engagement }\end{array}$ & 55 & $\mathrm{~F}$ & +.80 \\
\hline
\end{tabular}

By the end of Week 7, the relationships between engagement status and final course grades appear to be well established and did not fluctuate significantly for the duration of the course. What is interesting to note is that the relationship seems strongest on both extreme ends of the engagement scale. Very highly engaged students did exceptionally well in regard to their final course grade, while their counterparts on the very low engagement end had a very high probability of failing the course. Interestingly, the correlation between very low engagement and negative course outcomes may be even higher than demonstrated by this analysis since students who dropped the course were not included each week in the analysis since their engagement data is no longer calculated. It is likely that a large number of these students who dropped the course were in the lower engagement groupings at the time they withdrew from the course.

Week 8:

\begin{tabular}{|l|c|c|c|}
\hline Engagement Status & Number of Students & Anticipated Grade & $\begin{array}{c}\text { Correlation between Engagement and } \\
\text { Anticipated Final Grade }\end{array}$ \\
\hline $\begin{array}{l}\text { Very Highly } \\
\text { Engaged }\end{array}$ & 66 & $\mathrm{~A}$ & +.77 \\
\hline Highly Engaged & 63 & $\mathrm{~B}$ & +.61 \\
\hline $\begin{array}{l}\text { Moderately } \\
\text { Engaged }\end{array}$ & 81 & $\mathrm{C}$ & +.61 \\
\hline Low Engagement & 40 & $\mathrm{D}$ & +.64 \\
\hline $\begin{array}{l}\text { Very Low } \\
\text { Engagement }\end{array}$ & 51 & $\mathrm{~F}$ & +.81 \\
\hline
\end{tabular}


Week 9:

\begin{tabular}{|l|c|c|c|}
\hline Engagement Status & Number of Students & Anticipated Grade & $\begin{array}{c}\text { Correlation between Engagement and } \\
\text { Anticipated Final Grade }\end{array}$ \\
\hline $\begin{array}{l}\text { Very Highly } \\
\text { Engaged }\end{array}$ & 58 & $\mathrm{~A}$ & +.78 \\
\hline Highly Engaged & 59 & $\mathrm{~B}$ & +.63 \\
\hline $\begin{array}{l}\text { Moderately } \\
\text { Engaged }\end{array}$ & 80 & $\mathrm{C}$ & +.60 \\
\hline Low Engagement & 33 & $\mathrm{D}$ & +.61 \\
\hline $\begin{array}{l}\text { Very Low } \\
\text { Engagement }\end{array}$ & 49 & $\mathrm{~F}$ & +.83 \\
\hline
\end{tabular}

Week 10:

\begin{tabular}{|l|c|c|c|}
\hline Engagement Status & Number of Students & Anticipated Grade & $\begin{array}{c}\text { Correlation between Engagement and } \\
\text { Anticipated Final Grade }\end{array}$ \\
\hline $\begin{array}{l}\text { Very Highly } \\
\text { Engaged }\end{array}$ & 58 & $\mathrm{~A}$ & +.80 \\
\hline Highly Engaged & 50 & $\mathrm{~B}$ & +.64 \\
\hline $\begin{array}{l}\text { Moderately } \\
\text { Engaged }\end{array}$ & 84 & $\mathrm{C}$ & +.65 \\
\hline Low Engagement & 29 & $\mathrm{D}$ & +.66 \\
\hline $\begin{array}{l}\text { Very Low } \\
\text { Engagement }\end{array}$ & 50 & $\mathrm{~F}$ & +.85 \\
\hline
\end{tabular}

Week 11:

\begin{tabular}{|l|c|c|c|}
\hline Engagement Status & Number of Students & Anticipated Grade & $\begin{array}{c}\text { Correlation between Engagement and } \\
\text { Anticipated Final Grade }\end{array}$ \\
\hline $\begin{array}{l}\text { Very Highly } \\
\text { Engaged }\end{array}$ & 57 & $\mathrm{~A}$ & +.82 \\
\hline Highly Engaged & 51 & $\mathrm{~B}$ & +.66 \\
\hline $\begin{array}{l}\text { Moderately } \\
\text { Engaged }\end{array}$ & 80 & $\mathrm{C}$ & +.67 \\
\hline Low Engagement & 26 & $\mathrm{D}$ & +.67 \\
\hline $\begin{array}{l}\text { Very Low } \\
\text { Engagement }\end{array}$ & 42 & $\mathrm{~F}$ & +.86 \\
\hline
\end{tabular}

As anticipated, the Civitas Engagement App did become more closely associated with final grade outcomes by the end of the term. However it was surprising the degree to which there was only slight movement in correlations after Week 4.

\section{CONCLUSIONS}

It seems apparent from this study that the data obtained from the 'Engagement App' developed by Civitas and used at this university does have a relationship with final course grades. This presents some interesting conclusions. One, the algorithm used in calculating the 'Engagement Score' seems to very closely approximate the somewhat nebulous term 'engagement.' It is interesting to note that the App does not, in any appreciable way, measure 
'academic ability' or intrinsic intelligence. All factors measured are based more on persistence and participation rather than intelligence. The class that was the subject of the study was a freshman level introductory marketing course, which would naturally present less academically rigorous challenges than an upper level course. This may be one reason for the higher than expected degree of correlation between engagement and outcomes. It would prove interesting to see if this relationship holds true across different courses and different levels of rigor, where higher levels of thinking are potentially more impactful than higher levels of participation.

It was interesting that the most profound relationships existed on the extreme ends of engagement and outcomes. There seems to be greater flexibility and mobility between engagement statuses in the B,C, and D ranges than at the $\mathrm{A}$ and $\mathrm{F}$ range. It is possible that for much of the term the 'mid-range' engagement students fluctuate readily between the status levels while those on the extreme ends tend to be more rigid in their mobility. This seems also to be corroborated by the data. Of the students who were 'Very Highly Engaged' by week $2(\mathrm{n}=84), 53$ of them maintained that status for all 11 weeks $(63.1 \%)$, and those that were very low in week $2(n=34), 27$ either finished with an $\mathrm{F}$ grade or dropped the course before the end of the term (79.4\%).

Perhaps most interesting was the degree to which engagement status and final grades seem to sync up early in the term. As was discussed in the Results section, by Week 3 of the term variability in engagement status and final grades seemed to peak and remain relatively stable after that point (see Table 6).

Table 6. Weekly Engagement Score and Correlation to Final Grade

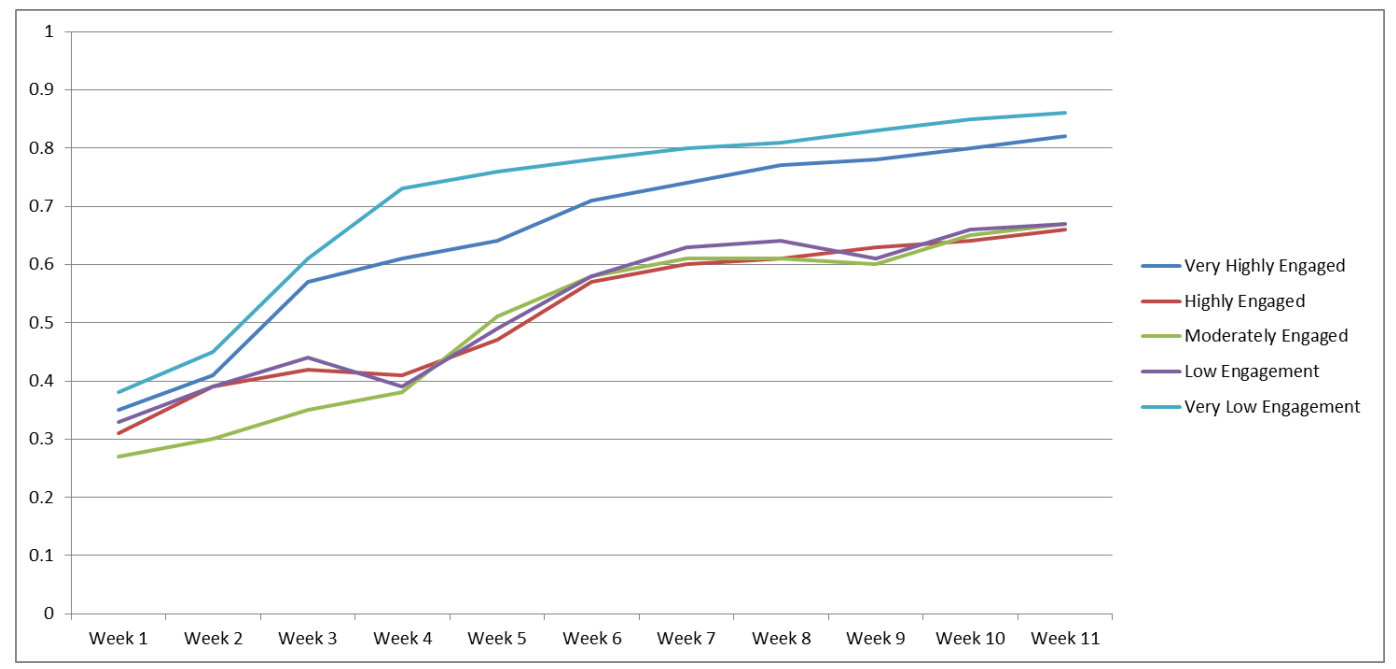

This presents interesting challenges and opportunities both for faculty teaching online and for universities developing courses and policies for online learning. Certainly one of the most compelling features of this App is that it provides faculty with almost real-time assessments on engagement, even before major assignments are due, which can assist faculty in developing early intervention strategies to assist at risk students and help them overcome these early barriers to success that seem quite significant in online courses. It also allows faculty to tailor messages to different groups based on changes in engagement status or other variables that might increase the likelihood of resonating with particular students. Of course, faculty must always be wary to not permit such data to create 'selffulfilling' prophecies about students on both ends of the engagement spectrum.

It is also interesting to note that the number of 'Very Highly Engaged' students dropped steadily throughout the term (see Table 7). This may also present some unique challenges to online faculty in maintaining the interest and participation levels of students: 
Table 7. Number of Students and their Engagement Status by Week:

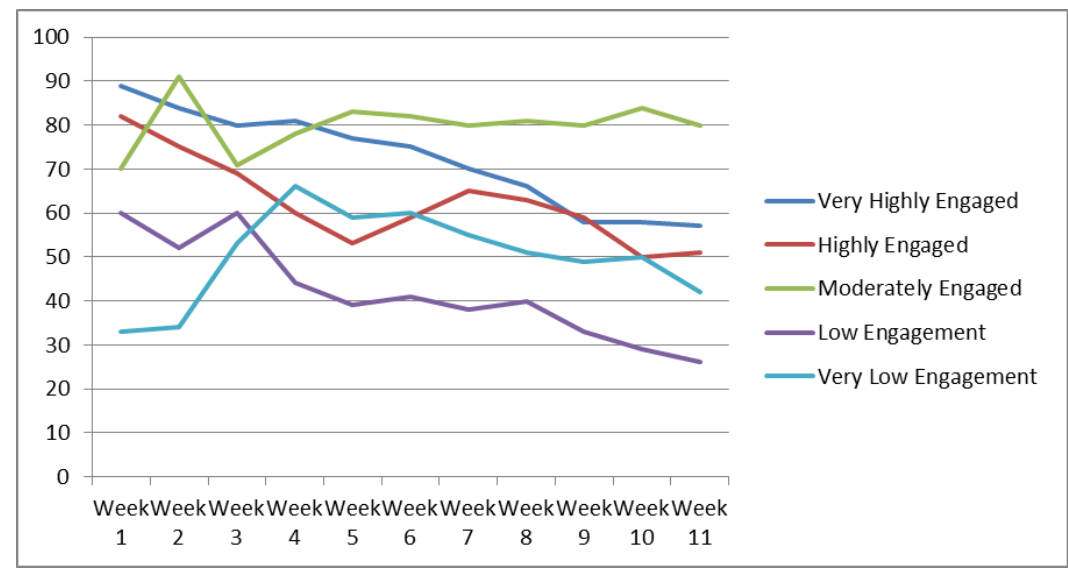

Another interesting conclusion from this study is the understanding that it may become increasingly important for online faculty to include instruction in 'becoming an engaged student' and presenting the importance of this attribute in student success. This may prove to be a critical success factor for faculty as they develop teaching strategies to drive engagement in online learning environments, given the strong correlations discussed in this study. This would require some development by faculty to devote both teaching time and course materials to 'teaching engagement' and convincing students that developing these 'engaging behaviors' in an online class, especially during the first few weeks, can be decisive in helping increase outcomes.

\section{LIMITATIONS OF THE STUDY}

While this study underscores the potential impact of Civitas (and possibly other software programs) to accurately relate course engagement and course outcomes, the sample size in this study was relatively small $(n=334)$ and it represents only one course (Introduction to Marketing) and only one professor. The impact of the professor and the course material itself may have also been influential factors in establishing relationships between engagement and outcomes, so the results must be viewed within that framework. It is also important to note that correlations do not imply causation and further research is needed to assess the causal relationship between engagement and outcomes. However, the results are promising that this type of analysis can create a potential tool for faculty to use in developing educational strategies and early interventions for at risk students.

\section{FUTURE RESEARCH}

The results of this study open up a number of interesting topics for future research. The continuing development of more sophisticated algorithms and other metrics for measuring the engagement of online students present numerous opportunities for further study. Additionally, assessing the variables that create 'engagement' in online courses may vary from course to course and may also be impacted by different university 'cultures' and could also represent an interesting and thoughtful area of study. As universities continue to expand their online offerings, research into software that can accurately 'predict' success for students will be an area of extensive new research.

\section{REFERENCES}

Allen, I. E., \& Seaman, J. (2008). Staying the course: Online education in the United States. The Sloan Consortium. Retrieved from http://www.sloanconsortium.org/publications/survey/pdf/staying_the_course.pdf 
Allen, I. E., \& Seaman, J. (2014). Grade change: Tracking online education in the United States. Retrieved March 24, 2016, from http://www.onlinelearningsurvey.com/reports/gradechange.pdf

Allen, I.E., Seaman, J., \& Sloan, C. (2007). Online nation: Five years of growth in online learning. Sloan Consortium.

Annand, D. (2011). Social presence within the community of inquiry framework. The International Review of Research in Open and Distance Learning, 12(5), 40-56.

Astin, A. (1999). Student involvement: A developmental theory for higher education. Journal of College Student Development, 40, 518-529.

Azvedo, R. (2015). Defining and measuring engagement and learning in science: Conceptual, theoretical, methodological, and analytical issues. Educational Psychologist, 50(1), 84-94.

doi:10.1080/00461520.2015.1004069

Benson, A. D. (2003). Assessing participant learning in online environments. New Directions for Adult and Continuing Education, 100, 69-78.

Brinthaupt, T., Fisher, L., Gardner, D., Raffo, D., \& Woodard, J. (2011). What the best online teachers shoulddo. MERLOT Journal of Online Learning and Teaching, 7(4), 515-524. Retrieved from http://jolt.merlot.org/vol7no4/brinthaupt_1211.htm

Burch, G. F., Heller, N. A., \& Freed, R. (2014). Back to the basics: Developing a student engagement survey to evaluate the role of experiential learning on student engagement. Developments in Business Simulation and Experiential Learning, 41, 204-214.

Carini, R., Kuh, G., \& Klein, S. (2006). Student engagement and student learning: Testing the linkages. Research in Higher Education, 47, 1-32.

Chen, P., Kuh, G., \& Gonyea, R. (2008). Learning at a distance: Engaged or not? Innovate Journal of Online Education, 4(3), 1-8.

Credence, B. (2010). The impact of instructor immediacy and presence for online student affective learning, cognition, and motivation. Journal of Educators Online (1), 1-30.

Dixon, M. D. (2015). Measuring student engagement in the online course. The online student engagement scale (OSE). Online Learning, 19(4), 143-156.

Draus, P., Curran, M., \& Trempus M. (2014). The influence of instructor-generated video content on student satisfaction with and engagement in asynchronous online classes. Journal of Online Learning \& Teaching, $10(2), 240-254$.

Durrington, V. A., Berryhill, A., \& Swafford, J. (2006). Strategies for enhancing student interactivity in an online environment. College Teaching, 54(1), 190-193.

Fredrickson, J. (2015). Online learning and student engagement: Assessing the impact of a collaborative writing requirement. Academy of Educational Leadership Journal, 19(3), 127-140.

Friedlander, J., MacDougall, P. (1992, Summer). Achieving student success through student involvement. Community College Review, (20)1, 20-28. doi:10.1177/009155219202000104 
Fuller, M.M., Wilson, M. A., \& Tobin, R. M. (2011). The national survey of student engagement as a predictor of undergraduate GPA: A cross sectional and longitudinal examination. Assessment \& Evaluation in Higher Education, 36(6), 735-748 doi:10.1080/02602938.2010.488791

Garrison, D. R., \& Cleveland-Innes, M. (2005). Facilitating cognitive presence in online learning: Interaction is not enough. The American Journal of Distance Education, 19(3), 133-148.

Handelsman, M. M., Briggs, W. L., Sullivan, N., \& Towler, A. (2005). A measure of college student course engagement. The Journal of Educational Research, 93(3), 184-191.

Harris, J. J., Sklar, B. M., Amend, R. W., \& Novalis-Marine, C. (2010). The growth characteristics and future of online CME. The Journal of Continuing Education in the Health Professions, 30(1), 3-10. Doi:10.1002/chp.20050

Hrastinski, S. (2009). A theory of online learning as online participation. Computers \& Education, 52,78-82.

Johnson, S. \& Aragon, S. (2003). An instructional strategy framework for online learning environments. New Directions for Adult and Continuing Education, 31-43.

Kuh, G.D. (2001). The National Survey of Student Engagement: Conceptual framework and overview of psychometric properties. Bloomington: Indiana University Center for Postsecondary Research.

Kuh, G. D. (March/April, 2003). What we are learning about student engagement from NSSE: Benchmarks for effective educational practices. Changes, 24-32.

Kuh, G.D., Cruce, T.M., Shoup, R., Kinzie, J., and Gonyea, R. (2008). Unmasking the effects of student engagement on first year college grades and persistence. The Journal of Higher Education, 79 (5), 540-63.

Kuh, G., Kinzie, J., Buckley, J., Bridges, B., \& Hayek, J. (2006). What matters to student success: A review of the literature. Washington, DC: National Postsecondary Education Cooperative Commissioned Paper. Retrieved from http://nces.ed.gov/npec/pdf/Kuh_Team_Report.pdf.

Kuh, G.D., Kinzie, J., Schuh, J.H., and Whitt, E.J. (2005). Assessing conditions to enhance educational effectiveness: The inventory for student engagement and success. San Francisco: Jossey-Bass.

Lewis, S. E., Freed, R., Heller, N.A., \& Burch, G. F. (2015). Does student engagement affect learning? An empirical investigation of student involvement theory. Academy of Business Research Journal, 28-16.

Lomax, R.G. (2001). An introduction to statistical concepts for education and behavioral sciences. Mahwah, NJ: Lawrence Erlbaum.

Miller, J. M. (2012). Finding what works online: Online course features that encourage engagement, completion and success (Doctoral dissertation). Retrieved from http://scholarworks.csun.edu

National Survey of Student Engagement. (2007). Construction of the 2007 NSSE Benchmarks. Retrieved from http://nsse.iub.edu/2007_Institutional_Report/Construction_of_the_NSSE_Benchmarks_and_Reliability_Indica tors.cfm

Nippard, E., \& Murphy, E. (2007). Social presence in the web-based synchronous secondary classroom. Canadian Journal of Learning and Technology, 33(1).

Ouimet, J. A., \& Smallwood, B. (2005). CLASSE - The class level survey of student engagement. Assessment Update, 17(6), 13-15. 
Pinsk, R., Curran, M, Poirier, R., \& Coulson G. (2014). Student perceptions of the use of student-generated video in online discussions as a mechanism to establish social presence for non-traditional students: A case study. Issues in Information Systems, (1), 267-276.

Robinson, C. C., \& Hullinger, H. (2008). New benchmarks in higher education: Student engagement in online learning [Electronic version]. Journal of Education for Business, 84(2), 101-109.

Shea, P., Li, C., \& Pickett, A. (2006). A study of teaching presence and student sense of learning community in fully online and web-enhanced college courses. The Internet and Higher Education, 9, 175-190.

Swerdzewski, P., Miller, B. J., and Mitchell, R. (2007). Investigating the validity of the National Survey of Student Engagement. Making differences through educational research: Bridging research and practice, . Rocky Hill, CT: Northeastern Educational Research Association.

Tello, S. (2007). An analysis of student persistence in online education. International Journal of Information and Communication Technology Education, 3(3), 47-62.

Yearwood, D. Y., Cox, R. J., \& Cassidy, A. A. (2016). Connection-engagement-empowerment: A course design model. Transformative Dialogues: Teaching \& Learning Journal, 8(3), 1-15. 